ECONOMICS

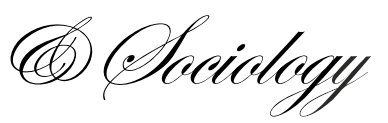

\author{
Elena Omelchenko, \\ National Research University \\ Higher School of Economics (NRU \\ HSE), \\ St Petersburg, Russian Federation, \\ E-mail:omelchenkoe@mail.ru
}

\author{
Yulia Andreeva, \\ National Research University \\ Higher School of Economics (NRU \\ HSE), \\ St Petersburg, Russian Federation, \\ E-mail:yulia.andre@gmail.com \\ Elvira Arif, \\ National Research University \\ Higher School of Economics (NRU \\ HSE), \\ St Petersburg, Russian Federation, \\ E-mail:elvira.ari@yandex.ru \\ Svyatoslav Polyakov, \\ National Research University \\ Higher School of Economics (NRU \\ HSE), \\ St Petersburg, Russian Federation, \\ E-mail:wek.spb@gmail.com
}

Received: March, 2016 1st Revision: July, 2016 Accepted: October, 2016

DOI: $10.14254 / 2071-$ 789X.2016/9-4/11

JEL Classification: Z13
Omelchenko, E., Andreeva, Y., Arif, E., Polyakov, S. (2016), Where Do Time and all of the Money go? Consumer Strategies of Urban Youth in Modern Russia, Economics and Sociology, Vol. 9, No 4, pp. 176-190. DOI: 10.14254/2071789X.2016/9-4/11

\section{WHERE DO TIME AND ALL OF THE MONEY GO? CONSUMER STRATEGIES OF URBAN YOUTH IN MODERN RUSSIA}

\begin{abstract}
The article focuses on consumer strategies of Russian urban youth during a financial crisis aggravated by European and North American sanctions against Russia. Prices on natural resources (namely, the drop in global oil prices) as well as the sanctions imposed by the countries that do not support Russia's policy toward Ukraine have become major causes of the 2015 crisis. This article offers a brief outline of the academic debate on youth consumption with a focus on post - and subcultural, problematised and lifestyle-related lines of research. We touch upon such topics as informed and stimulated consumption actualised by the crisis. The analysis of urban youth consumption draws on the data of a research project; its empirical basis consists of sixty semi-structured interviews conducted with two generations of young people in St. Petersburg (20-25 and 30-35 years old) with different job tenure (no more than five years and about ten years) and from different fields of employment: the public sector (budget-funded organisations), the private sector (commercial companies) and self-employment (freelancers). Our particular attention to the changes in young people's financial and time budgeting practices stems from the hypothesis that they are the main manifestations of youth's first reactions to the crisis. The key questions of the analysis are as follows. How do young people with different work experience spend their time and money? Does the ongoing crisis establish new consumer behaviour patterns among urban youth in modern Russia?
\end{abstract}

Keywords: youth, consumption, employment, social and economic stratification, Russia. 
consumer trends. At the same time, youth consumption issues related to the nature of young people's employment and rootedness in regional labour markets, especially in a challenging economic environment, remain in the sidelines. Large-scale surveys present a palette of consumer preferences that are rarely linked to job tenure, and relate mainly to the changes in young people's attitude towards consumable goods (Synovate Comcon, 2015).

Despite the changes in economic conditions, the everyday life of today's youth is still rich in various consumer offers, and consumption remains as both a form and a background for the development of youth styles. Being a part of a consumer group is one of the foundations upon which young people construct their identities. This factor becomes all the more important in a fast-changing economic environment with new options emerging more and more frequently. The new architectures of consumer offers are encouraging young people, the part of the population that is the most susceptible to market novelties, to integrate themselves into the situation, constantly producing their identities, (in)directly joining the race for the fashionable, prestigious and relevant. It is obvious, however, that the participants' progress and success rate differ greatly. Some find that access to the style supermarket is denied for them, and consumer freedom is just an illusion linked with complex feelings of exclusion and deprivation. This is not a feature peculiar to Russia, but an overall trend of growing structural and systemic inequality that accompanies the large-scale development of the global market. Until today, distinctive features of Russian consumption were mainly defined by the concept of 'consumer revolution' applicable to the countries that have moved 'from necessary consumption to overconsumption' (Gurova, 2009, p. 276). Nevertheless, the situation is changing nowadays. We observe a partial return to shortage practices, which is due to not only the reduction and phasing of imported goods on offer as a consequence of the sanctions, but also an obvious decline in the standard of living for a significant part of the population that is hit by the economic crisis the hardest - the poor, the retired, the unemployed. Changes in consumption patterns of other, more secure population groups might not be as noticeable, and working youth is an example of that. However, this does not mean that young people do not feel the pressure of the crisis. A number of social scientists consider generational differences to be a new form of inequality (Pilkington, 2006, p. 383), so it was important for us to test the differences between young consumers with different labour and generational experiences employed in different fields: the public sector, the private sector, and the self-employed (freelancers). We believe that the field of employment can affect both the availability of material and symbolic resources and the habitus formed during young people's professional development, when they are learning the rules and regulations of a particular employment sector.

\section{Youth consumption as the focus of current academic debate}

The contemporary academic debate on youth consumption is developing in several, rarely intersecting, dimensions. First of all, subculturally, consumer strategies and patterns are viewed as a new form of creating social differences. This dimension stems from young people's resistance against the class position inherited from their parents (Abraham, 2013). Subcultural research develops the idea of individual and group style values. Young people are no longer viewed through the rituals of resistance against their class origin, and the concept of the mobility of youth cultures leads to the idea of fragmented youth styles, mainly focusing on the features of consumer practices of so-called progressive youth (Bennett, 2011; Hodkinson, 2012; Omelchenko \& Pilkington, 2013). However, they are also interested in the emergence of mainstream cultural products (new forms of cultural domination), around which the 'authentic' individual and group tastes of the youth are formed (Weinzierl \& Muggleton, 2003). 
The second dimension concerns problematised habits. Here, we focus on 'ordinary' youth (as opposed to those who belong to a subculture). We study their passions (hobbies, 'addictions'), which are initially considered to be a threat to young people themselves and society as a whole. The prevailing lines of research concern alcohol drinking, tobacco smoking, drug abuse and excessive fast food consumption. In the last decades, researchers have been paying more attention to shopaholism, internet addiction and particular style (and food) practices of young people. Within this approach, young people are viewed as hedonistic and greedy consumers concerned only with the pursuit of pleasure (Miles, 2000), completely beyond the influence of adults' social authority (Benson, 2000).

Thirdly, we consider the lifestyle-related dimension of youth consumption. In this respect, researchers normally focus on everyday practices of identity construction (related to gender, style and professional status). Their studies emphasise the subjective and initiative aspects of youth consumption; researchers turn to the peculiarities of consumer strategies in the context of structural constraints, existing inequalities, and available resources that give various groups access to the style supermarket of modern societies (or deny such access). Researchers believe that, in a risk society, young people are capable of constructing their own 'lifestyles' more or less by themselves; not through the perception and adaptation of the existing standards, but through acquiring skills that help them provide for themselves and organise their lives as 'an open process' (Beck, 2009). Young people can change their cultural strategies; they do not feel as if they have to adhere to one style forever, and consumption can become a struggle to remain a part of one's peer group and not to become an outsider while following a certain style (Omelchenko \& Sabirova, 2015; Hodkinson \& Deicke, 2007). Nevertheless, not everyone has access to the 'consumer supermarket', and structural restraints (from bodily to social ones) continue to influence young people's consumption profiles (Shildrick \& MacDonald, 2006). Meanings, as well as individual and group interpretations of consumer preferences, continue to depend on one's position in the labour market (both young people's and their parents'), gender and ethnicity. Another issue is how one's opportunities are used and redefined within peer groups, as young people are engaged in both global trends and local cultural landscapes.

It should be noted that the recent debate that touches upon the stylistic peculiarities of youth consumer practices is of fragmented nature. Here we will focus on the most apparent issues in 'style' consumption studies, namely on the research of informed and stimulated consumption. Researchers generally consider informed consumption to be of a political nature. One of the most relevant topics is political consumerism - the study of consumer ethics in the context of civic engagement (Ward Claes de Vreese, 2011). Authors note the spread of this phenomena; in particular, the online discussion of informed (civil) consumption is connected with offline political activity, and the idea of passive consumption is being replaced by prosumerism, with young people increasingly demanding to have a voice and willing to take part in what is sold and how it is sold (Salzman, 2000). Manufacturers, in their turn, tend to respond to young people's growing interest in informed consumption, emphasising ethical issues in advertising and thereby forming new stylistic consumer profiles (Scammell, 2000).

Researchers use the category of 'stimulated consumption' to emphasise the role of various structural constraints (from bodily to social ones) in studying (mobile) youth cultures' consumption (Hodkinson, 2007; Shildrick \& MacDonald, 2006). In our opinion, a financial crisis can act as such a structural condition influencing youth consumption. Limited access to money can hinder young people's full involvement in their 'inside' groups and lead to social isolation not only from the core activities that facilitate socialisation, but also from activities that play a significant part in demonstrating one's commitment to a style they choose (Croghan et al., 2006, p. 474). Forced awareness may be one of young consumer's reactions to 
the crisis, when maintaining an adequate consumption level becomes a necessity controlled by a sense of guilt and supported by moral reasoning (Brown \& Spencer, 2013).

Volatile economy leads to transformations in financial behaviour, heightened awareness and an increased role of forced practices, as young people's dependence on regular income is being tested. We also believe that the importance of other resources increase. First of all, it is time, which is invested in consumption along with the money. Larger portions of time are allocated for work as leisure time shrinks, which results in fewer consumption opportunities and partial abandonment of consumers' claims (Radayev, 2005).

The importance of time as a resource in studying consumption in the new environment also underscores the fact that, during a crisis, people begin to intentionally manage their time, projecting the expenses on goods and services (Tsai \& Zhao, 2011).

Leisure time begins to be considered a value only if it allows you to be in sync with your social environment: friends, family, community (Chatzitheochari \& Arber, 2012).

In a broader context, time deficit underscores the importance of studying time budget and spending. Researchers point out that time deficit is an indicator of social inequality that stems from the practice of combining professional and personal circumstances (Epstein \& Kalleberg, 2004).

Therefore, our attention to connection and interdependence between financial behaviour and time consumption is not accidental. Time is becoming one of the key resources nowadays. Life schedules and the ratio of leisure and work time can help to see micro changes in consumer profiles of young people forced to change or keep their consumer habits. Not only the transformations of financial behaviour that depend on changes in income (volume, stability, sources, and, therefore, strategies), but also the ability to manage one's time define the new consumer practices of young people.

\section{Consumer behaviour of young people during a crisis in Russia}

Russian experts point out that prices on natural resources (namely, the drop in global oil prices) as well as the sanctions imposed by the countries that do not support Russia's policy toward Ukraine have become major causes of the 2015 crisis. The Federal State Statistics Service has published an assessment of Russia's GDP in the second quarter of 2015: the economic downturn has accelerated more than twice, up to $4.6 \%$ after a $2.2 \%$ drop in the first quarter (Federal State Statistics Service..., 2015). Thus, the sanctions have further aggravated the overall negative socioeconomic situation.

In the advanced economies, 'the consumer society emerged with the development of capitalism, accompanied by strong economic and technological progress and social changes: higher incomes, more free time, the blurred class structure, the individualisation of consumption' (Koftunkin, 2011). In Russia, consumption growth is associated with an increase in the export of all categories of goods and not with the development of market relations. Market saturation in Russia happened faster than the formation of textual and symbolic components of consumption. For young people growing up in the post-Soviet years, consumer practices, competences and their symbolic meanings were being formed while their parents' experience as 'Soviet consumers' was transforming in the changing ideology and consumption practices. Structural conditions of Russian society have contributed to the fact that consumption 'was and is developing along a "special path" - the meaning of things, the attitude towards them, the variety of goods and purchase planning is now often realised "with regard to the Soviet era," and the experience of the "Soviet consumer" partly structures the current Russian consumption' (People and things..., 2005, p. 5). However, in the context of a 'consumption revolution', the compliance of Russian society with Western consumption standards 'applies only to some Russian territories, forming small areas of the "real 
consumption" practice' (Vtorushina, 2011, p. 259). Such territories include big Russian cities like St. Petersburg, which, along with Moscow, has become one of the first places with 'Western-type shopping about areas' (Ilyin, 2005, p. 31).

According to researchers, the use of Western theoretical approaches to the analysis of consumption in transition societies, Russia being one of them, requires "re-evaluation with regard to the sociocultural and economic reality of the former Soviet republics" (Lintsova, 2014, p. 204). However, it can be used in the description of consumption trends.

Economic volatility and cultural pressure, which shape the models of successful public youth consumption, are the conditions of youth socialisation both globally and in Russia. A survey of Russian youth has showed that members of this group were not ready to 'lower their consumer demands' (The Dynamics of the Crisis..., 2009) in times of a global financial crisis. According to the results of various surveys, Russian youth judged the global crisis 'by the number of shopping centres, their product range, ongoing construction projects and the frequency of citywide celebrations' (Lukyanova \& Sabirova, 2012, p. 83).

The new crisis 'caused by external factors, such as sanctions and dropping oil prices, struck in late 2014, and the way out may be slow and drawn-out, almost like a stagnation' (Klepach, 2015, p. 210). At the same time, '70.7 respondents believe that Russia should continue its policy, despite the sanctions' (Youth's Reserved Attitude..., 2015). Despite defining the situation in the country as an economic crisis (How the Crisis..., 2015) and demonstrating their readiness for a change in the product range of shopping centres, young men and women focus primarily on their taste when they choose goods and do not reduce their consumption (Consumer Behaviour..., 2015).

\section{Empirical basis and methodology}

The empirical basis of the article contains the data collected during the joint project Youth Solidarities and Generations of the 21st century: the Value of Labour and Consumption ${ }^{1}$.

Sixty young, working St. Petersburg residents took part in the study through semistructured interviews. The respondents were equally represented by men and women (thirty people in each group) and two age cohorts (thirty people aged 30-35 and thirty people aged 20-25).

The respondents were selected based on their work experience and job tenure. This was about/more than ten years for 30-year-olds and three to five years for 20-year-olds. Each stratum consists of three groups: the first group includes people employed in the private sector (having permanent contracts with large and medium-sized enterprises); the second group consists of people who work in budget-funded organisations; and the third group comprises the self-employed (so-called freelancers and entrepreneurs that own a business with no more than five employees). Twenty interviews were conducted in each group (Table 1).

\footnotetext{
${ }^{1}$ The results of the project 'Youth Solidarities and Generations of the 21st century: the Value of Labour and Consumption', carried out within the framework of the Basic Research Program at the National Research University Higher School of Economics (HSE) in 2014, are presented in this article.
} 
Table 1. Respondents' field of employment

\begin{tabular}{|c|c|c|c|c|}
\hline & \multicolumn{2}{|c|}{$20-25$} & \multicolumn{2}{|c|}{$30-35$} \\
\hline & male & Female & male & female \\
\hline $\begin{array}{l}\text { Business } \\
\text { (large and } \\
\text { medium- } \\
\text { sized) }\end{array}$ & $\begin{array}{l}\text { HR, } \\
\text { bank employee, } \\
\text { marketer, } \\
\text { marketing } \\
\text { manager, } \\
\text { waiter in a large } \\
\text { chain }\end{array}$ & $\begin{array}{l}\text { Shop assistant } \\
\text { (lingerie chain), } \\
\text { engineer, } \\
\text { HR manager, } \\
\text { EF department } \\
\text { director, } \\
\text { lawyer }\end{array}$ & $\begin{array}{l}\text { Engineer, } \\
\text { lawyer, } \\
\text { CEO, } \\
\text { programmer, } \\
\text { designer }\end{array}$ & $\begin{array}{l}\text { Employee in a large } \\
\text { corporation, } \\
\text { manager at a plant, } \\
\text { insurance specialist, } \\
\text { assistant director in a } \\
\text { bank, } \\
\text { lawyer in a large } \\
\text { corporation }\end{array}$ \\
\hline $\begin{array}{l}\text { Civil } \\
\text { servants and } \\
\text { public sector } \\
\text { employees }\end{array}$ & $\begin{array}{l}\text { Actor, } \\
\text { state early } \\
\text { treatment centre } \\
\text { employee, } \\
\text { graduate student, } \\
\text { receptionist, } \\
\text { school teacher, } \\
\text { museum } \\
\text { employee }\end{array}$ & $\begin{array}{l}\text { School teacher, } \\
\text { government } \\
\text { official, } \\
\text { English teacher, } \\
\text { nurse, employee } \\
\text { at a centre for } \\
\text { family assistance }\end{array}$ & $\begin{array}{l}\text { Social worker, } \\
\text { teacher, } \\
\text { museum employee, } \\
\text { academic } \\
\text { researcher, } \\
\text { system } \\
\text { administrator at a } \\
\text { library }\end{array}$ & $\begin{array}{l}\text { Administration } \\
\text { employee, } \\
\text { web editor on TV, } \\
\text { teacher, } \\
\text { assistant } \\
\text { kindergarten teacher, } \\
\text { actress }\end{array}$ \\
\hline $\begin{array}{l}\text { Self- } \\
\text { employed } \\
\text { (freelancers } \\
\text { and private } \\
\text { entrepreneurs) }\end{array}$ & $\begin{array}{l}\text { Real estate agent, } \\
\text { TV station } \\
\text { employee, club } \\
\text { owner, } \\
\text { temporary } \\
\text { university } \\
\text { lecturer, } \\
\text { tree feller, } \\
\text { freelancer }\end{array}$ & $\begin{array}{l}\text { Bakery owner, } \\
\text { freelance } \\
\text { photographer, } \\
\text { tailor shop } \\
\text { owner, } \\
\text { private trader, } \\
\text { freelancer }\end{array}$ & $\begin{array}{l}\text { Entrepreneur, } \\
\text { freelancer at an } \\
\text { Internet company, } \\
\text { political } \\
\text { consultant, } \\
\text { journalist, } \\
\text { music festival } \\
\text { planner }\end{array}$ & $\begin{array}{l}\text { Stylist, hair salon } \\
\text { owner, } \\
\text { in-home cost } \\
\text { consultant, } \\
\text { editor, } \\
\text { designer, } \\
\text { editor }\end{array}$ \\
\hline
\end{tabular}

More than half of the respondents were single. The share of married respondents was, of course, larger in the age cohort of 30-year-olds (see Table 1). Twelve respondents from the group of 30-year-olds have underage children.

Table 2. Respondents' marital status by age cohort (number of people)

\begin{tabular}{lllccc} 
& & \multicolumn{3}{c}{$\begin{array}{c}\text { thirty-year- } \\
\text { olds }\end{array}$} & $\begin{array}{c}\text { twenty-year- } \\
\text { olds }\end{array}$ \\
\hline \multirow{2}{*}{} & single & Number & 15 & 26 & 41 \\
\cline { 2 - 6 } & married & Number & 12 & 4 & 16 \\
\cline { 2 - 6 } & divorced & Number & 3 & 0 & 3 \\
\hline & Number & 30 & 30 & 60 \\
\hline
\end{tabular}

The two age groups significantly differ in terms of their housing conditions. Among the 30-year-olds, there is a significantly larger share of people who have their own residential property, while more than half of 20 -year-old informants (16 people) live with their parents and partners. In terms of the respondents' fields of employment, it should be noted that most public sector employees live with their parents or partners, regardless of age. 
Table 3. Respondents' housing conditions by age cohort and by field of employment (number of people)

\begin{tabular}{|c|c|c|c|c|c|c|c|}
\hline & \multicolumn{3}{|c|}{ thirty-year-olds } & \multicolumn{3}{|c|}{ twenty-year-olds } & \multirow[b]{2}{*}{ Total } \\
\hline & business & $\begin{array}{l}\text { public } \\
\text { sector }\end{array}$ & $\begin{array}{c}\text { self- } \\
\text { employed }\end{array}$ & business & $\begin{array}{l}\text { public } \\
\text { sector }\end{array}$ & $\begin{array}{c}\text { self- } \\
\text { employed }\end{array}$ & \\
\hline live in a hostel & 0 & 0 & 0 & 1 & 0 & 0 & 1 \\
\hline rent a dwelling & 3 & 2 & 4 & 5 & 0 & 5 & 19 \\
\hline $\begin{array}{c}\text { live with } \\
\text { parents/partner }\end{array}$ & 2 & 5 & 1 & 3 & 8 & 5 & 24 \\
\hline $\begin{array}{c}\text { residential } \\
\text { property owners }\end{array}$ & 5 & 3 & 3 & 1 & 2 & 2 & 16 \\
\hline
\end{tabular}

The respondents' monthly personal income ranges from 10 to 150 thousand roubles. Their average monthly personal income amounts to 52,600 roubles with the median at 48 thousand roubles. When compared, median incomes of the two age cohorts revealed a significant contrast: 60 thousand roubles (30-year-olds) and 35 thousand roubles (20-yearolds).

The sample proved to be rather homogeneous in terms of the respondents' educational background. The vast majority of informants (48 people) have higher education without an academic degree, ten informants have vocational secondary education or incomplete higher education, and two informants are candidates of sciences ( $\mathrm{PhD}$ candidates) (see Table 3).

During the interviews, the respondents were asked to identify their main expense areas (What is your monthly income mostly spent on?). The most frequent responses are presented in Table 4. The table shows that the main items of expenditure in both cohorts are food, clothing, cafés and restaurants, and utility bills. Differences in the spending patterns of 20and 30-year-olds (see Table 3) are primarily manifested in the categories only peculiar to the cohort of 30-year-olds: mortgage and children. This group's spending pattern shifts towards household expenses (food, utilities, car service), while among 20-year-olds there are more respondents whose costs are determined by leisure consumption, including cafés and restaurants, as well as additional education and personal development activities (foreign language courses, interest groups, etc.). In addition, there are more 20-year-olds whose monthly expenses include the purchase of clothing.

Table 4. Main expense areas by cohort (answers)

\begin{tabular}{lcc}
\hline & Twenty-year-olds & Thirty-year-olds \\
\hline Food & 16 & 25 \\
\hline Clothes & 10 & 6 \\
\hline Cafés and restaurants & 10 & 7 \\
\hline Utility bills & 5 & 8 \\
\hline Mortgage & 0 & 7 \\
\hline Children & 0 & 5 \\
\hline Education, personal development & 5 & 2 \\
\hline Car service & 2 & 4 \\
\hline
\end{tabular}

The main methodological framework of the study was qualitative methodology. The logic of the analysis of the collected data corresponds to the logic of the Grounded theory (Strauss \& Corbin, 1998). The choice of methodology is based on both the specific features of the object of research and the general social and economic context of the risk society (Beck, 2009). In the new world of increasing uncertainty (economic, political, labour, existential), it 
is difficult to talk about the predetermined nature or straightforward correlation of consumer behaviour with class and occupational structures. The process of individualisation that characterises the risk society makes private biographies and the meanings and values that individuals attribute to consumption more significant. Consumption strategies of today's Russian youth are connected (though indirectly) with not only the financial freedom of young people, social and cultural capitals of their parents' families and peer groups, but also with (creative) means of identity formation and the manifestations of subjective initiative. Qualitative methods make it possible to capture and describe the diversity of styles and social logics of consumption that cannot be reduced to the status and role-playing dispositions, which are formed both inside and at the intersection of different social fields (work, education, leisure, family).

During the interviews, we discussed various topics: the informants' attitude to their occupation, the nature of their work, their ideas of success, expenses and financial practices, consumer preferences and the nature of free-time activities, stylistic peculiarities and hobbies. Each of these topics can become a focus of a separate analysis.

This article focuses on the analysis of working youth's consumer strategies manifested in the practices of time distribution and financial behaviour - the spending and purchasing system. Time and money are considered key resources, and their consumption largely defines consumption styles and choices.

\section{Time as a significant consumption resource}

In the context of an ongoing crisis, time becomes a consumption resource that is just as valuable as money, social networks, professional and personal competences. Significant changes in structural conditions contribute to the fact that many young people are forced to reconsider and reshape their hierarchy of priorities, wondering 'what am I willing to spend my time on today?'

First of all, 'time monetisation' proved to be the main consumption trend among young people with different work experience in all three job sectors:

'You realise that your time is money... I have translation jobs as well as tutoring. And you start realising how much time you have spent on something and how much money you got for it. ...the price of an hour of your time starts to make sense... when you waste an hour, you lose money...' (female, 23, school teacher).

'It's just that if I am paid less than I'm worth, I will feel unappreciated... It is really sad when you work around the clock and they pay you half as much...' (female, 25, HR manager).

The interview analysis suggests that the ability to manage your own time is especially valued by young people in an unstable economic environment. Spending systems, financial practices, leisure and cultural consumption trends prove to have a direct correlation with how much time young people have, how well they manage it and how they organise their priorities.

Secondly, the line between work and other areas of life is blurred. It has turned out that the crisis makes young people switch to a more positive attitude towards the combination of different types of employment. In the interviews, sources of personal income could include practically contradictory jobs that the respondent would describe as, for instance, 'my main job', 'a side job', and 'it's just a temporary thing'. The trend of 'blurred lines' is the most apparent among freelancers. The nature of self-employment has erased the boundaries between their work and free time. It seems as if self-employed youth have no 'days off' or 'holidays' whatsoever. For instance, this is a quote from an interview where the respondent uses the vernacular for a holiday that originated as a day of solidarity of women workers in the fight for equal rights, and is now annually celebrated in Russia as the 'Women's Day': 
'...I have absolutely no need for public holidays. So, fine, it's March 8, it's a holiday and I'm working - no problem!' (female, 21, bakery owner).

It would seem that it should be easier for freelancers to deal with the time management issue than for public and private sector employees. Freelancers are the masters of their own time, and even if they do depend on the employer, it is indirectly. They can decide how much they should work and how much time off they should have. However, during the crisis, the self-employed are, to some extent, losing control over their own time. The need to constantly look for earnings leads to the fact that their work schedule is overly flexible and is constantly being adjusted to specific tasks. As a result, self-employed youth have to invest more resources, their prospects remaining unclear. Therefore, we can hardly say that they find it easier to adjust to sanctions-related economic changes than young people in other professional groups.

'There are friends whom I have photographed. They tell their friends about me, then they call me: "I want a photo shoot" or "it's my child's birthday", or "it's our wedding"... So, it's [through] social networks or through the grapevine... someone tells someone else, and so on. ... (I work), every other day sometimes. There can be nothing at all for two weeks... Drawback of the job ... I never know what happens next. There are some orders that people place in advance, like weddings. But the thing with weddings is that something can change, or whatever... ... Most often, I have some orders for a while. Then I work on the photos, process them...' (female, 25, photographer).

The blurred boundaries between work and leisure are not only peculiar to the selfemployed. Young entrepreneurs and public sector employees also indicate that the line between work and hobbies can shift. However, this trend has some specific features. Hobbies merge with work, complementing it, and work is perceived and interpreted as more of a leisure practice:

'Just like anyone, I watch an inordinate amount of TV series... Also, translating; I like it, and sometimes you get really enjoyable texts that make you happy when the translation comes out right. I don't really earn my living with it, and tutoring also feels like a hobby... so, maybe tutoring and translating are my main hobbies' (female, 23, school teacher).

Therefore, in case of young people in the private and (to some extent) in the public sectors, the occupational status of employment shifts in meaning. Work is not so much a means to earn one's living as an activity. The unfolding crisis gradually leads to both direct and indirect reduction of wages. In these unstable conditions, employees hold onto their jobs, so it becomes common among employers (in both the private and the public sector) to suspend their staff or reduce their working hours, which results in a lower income. Therefore, it is more and more often that young people in both the public and the private sectors feel the instability and the temporary nature of their job.

The third trend is manifested in the fact that leisure consumption has been forced into private (home) space. Cultural time conversion practices take peculiar shapes here: staying at home, having lazy weekends or home get-togethers and going to one's country house. Lazy days off usually include hanging out with friends, drinking, watching videos, films or TV shows together.

'Nothing special - you wander around the flat, surf the Internet for a while, work a bit, do some cleaning up. That's it, I guess... Well, go for a walk maybe' (male, 32, teacher).

'I spend weekends at home sometimes; you want to relax, to have a break from it all. ... I lay at home, watch TV shows, do nothing' (male, 25, psychologist in a state early treatment centre).

'In summer, I sometimes go to the beach and play volleyball there, because of the [good] weather. This weekend, too ... Well, there is always something like that. (But) sometimes I get tired, and I can watch TV shows in bed all day long' (female, 25, HR manager, 2014 data). 
'At the weekend, I meet up with my friends; we sit and tell each other our news, talk about something - our mutual friends, plans, politics or whatever. We play some games or something, so, there you go. Then, I tidy up at home. Well, some household things like the washing-up' (male, 31, manager in a company).

We believe that the private 'lazy' pastime is so popular not only due to young people's saving practices, but also because it allows to do several activities at the same time, including work and leisure. This 'combining' trend creates an (often misleading) impression that they can manipulate events, be on time everywhere, and control their time.

Thus, time management practices of young people with different work experience have proved to have more similarities than differences. Young public sector employees, and, to a greater extent, private sector employees, start considering their time spending habits carefully, just like money spending. Additionally, their leisure practices shift from the public into the private (home) environment. The so-called 'freelancers' try to do as much as possible in their working hours, and they are willing to sacrifice traditional leisure, combining it with their job activities. Today, young people are especially acutely aware of how much their time is worth and they have to exert a lot of effort to control and really manage their time. An apparent overlap between the groups is that they (are forced to) exhibit similar time management practices: time monetisation, predominance of home pastime, and work taking over free time.

\section{Differences in the financial behaviour of urban youth with different job tenure}

The analysis of the academic debate on youth consumption in the first part of the article shows that the most important distinctive features can be attributed to structural conditions, which can involve such circumstances of urban youth's lives as getting married, starting a family, and leaving home. It is also obvious that the financial behaviour and its transformation can depend on personal factors: whether one has any long-term plans, the way one deals with momentary wishes, and so on. However, in the context of the unfavourable economic environment in Russia, we decided to analyse the data in detail and identify the most notable trends in the financial behaviour of urban youth.

Overall, it is important to note that young people with a longer job tenure (about ten years) prefer to plan their financial behaviour. There are some differences in planning strategies that are partially defined by the field of employment of young men and women. Young private sector employees tend to plan for the longer term. They are driven by pragmatic calculations in almost every respect, from buying a shirt to choosing a recreational facility:

'I've been wanting to go to [this place on the] Fontanka [embankment]. Where they sell those bagels. BagleFoodMarket or something... hipsters always go there; and I thought I should go and see... So, I ordered this bagel. It cost 200 roubles or so. I really didn't get what I'd paid for... Well, it's kind of nice - the bun, the chicken breast, and it's sprinkled with some curry you know ... Some sort of a light cream sauce, a tomato slice and some lettuce. Well, I really didn't get it... I paid my money for it. I think it's overpriced...' (male, 32, engineer in a commercial company).

Self-employed interviewees plan their business expenses, primarily their investments, before everything else and then they carefully consider where to buy things and how much to spend. Compulsive consumption becomes a relic of the past, young people are now prudent in their spending; they require high quality and prefer imported goods:

'Well, yes, a limited number of clothes, but I usually shop online, through foreign websites; I look for and wait for sales... I like good clothes, expensive clothes; well, relatively expensive, I look for high quality... I mostly shop at [website name] now. I have never bought anything in 
Saint Petersburg. When I was single and had more freedom, I would go to Finland and shop there' (female, 30, editor, freelance).

The strategy of public sector employees' financial behaviour planning has proved to be closely related to saving practices:

'I save on everything. (laughs) I always count everything - what I've spent on this, on that, and... what I am saving for' (female, 31, assistant kindergarten teacher).

Their actual expenses are planned, but their purchasing practices are integrated into their daily routine. They shop either on the way home from work or while hanging out with friends. Overall, one cannot call their consumer strategies innovative; when they buy a gadget, their choice is usually determined by a rational approach - (Respondent talks about a new smartphone model) 'I will buy it when I know why I need it'.

Different trends in everyday spending are also important in order to understand financial planning. For instance, young people in the private sector are focused on brandname clothes, gadgets, nice cars, and buying their own flats:

'I am crazy about iPhones. As soon as a new one comes out, I just have to go and buy it at once...I have all their products' (female, 30, a specialist in a corporation).

Real practices of young public sector employees amount to a list of essentials: food, transport, telephone, and Internet bills. The importance of status in relation to consumption is determined by how much their appearance matches their occupation: 'clothes that aren't too trendy and flashy' (male, 32, teacher).

The set of essentials of self-employed respondents is shaped by their job sector, which defines their preferences. They choose goods according to their usefulness and performance, but a car and a flat are once again at the top of the list.

Thus, we can talk about two financial planning strategies of young people with about ten years of work experience. They are defined by planning goals and do not demonstrate any major transformations. These spending strategies are passive and are still moving along the usual path. Private sector employees plan their expenses in order to maintain and improve their status, those who work in the public sector seek to maintain their living standards, and self-employed youth tend to self-invest.

The financial behaviour of young people new to the labour market is entirely different. This cohort is characterised by a short planning horizon and the lack of long-term plans. They feel less confident in the context of the labour market; their financial plans are short-term, the horizon of their prospects is limited to a calendar year at best: 'In five years? It's just white noise, really...' (female, 25, HR manager). This makes their financial behaviour uneven, spontaneous and contextual: 'I have a very strange attitude to money - I'm a terrible spender. If I have the money, I spend it quickly - I know that I will have another salary, and if not, I start to save all of a sudden for some reason' (female, 22, sales manager). On the one hand, the respondents say that they do not need to count the money they spend: 'If I need to, I will go and make some more' (male, 22, waiter). On the other hand, parents continue to help these young people and play the part of an important financial resource in the spending and consumption system of young people in this group - they pay for food, mortgage, accommodation, and education. At the same time, their consumption stays separate from that of their parents. This generation uses the phrase 'my own money' when they talk about their expenses. Whether a young person lives alone, with a partner or with their parents is irrelevant - 'their own money' is not included in the context of everyday shopping for family needs and is considered to be a social life and entertainment resource. It is not contributed to the family budget, but spent on either additional shopping or entertainment. It is 'their own money' that becomes their key resource for various (at times quite austere) saving practices, including cutting back on food shopping: 'I find it the hardest to spend money on food. You 
eat it and that's it, there is nothing left' (male, 25, psychologist in a state early treatment centre).

The main expense area of private sector employees consists of trendy and desired items. Young people do not just copy what they see, they try different styles and experiences. For example, they can spend the whole salary and the bonus on a fashionable watch or on a new model of a player or a laptop - not necessarily the most expensive ones. The habit of changing things regularly persists, especially if parents can pay most of the expenses.

Public sector employees fulfil their communicative needs through consumption; spending time with their friends is an important motivator:

'I go shopping at least once a month. Sometimes I want to buy something, sometimes I just go there socially, to hang out with friends, and eventually buy something' (female, 23, school teacher).

To make the process of choosing easier they maintain a personal style that they have already chosen:

'I don't shop around... I know the type of this coat, for example. I guess, when I buy a new one, they are all alike... and the shoe style is basically the same' (male, 25, psychologist in a state early treatment centre, postgraduate student).

Self-employed youth establish a rational spending system: 'I have all Apple devices because they are convenient and easy to use' (male, 23, works on television, a club owner). Even clothes are seen as a sustainable investment.

Thus, the financial behaviour of young people who are new to the labour market is uneven; they do not have a sensible spending strategy. This imbalance leads to the fact that young people with shorter job tenure cannot refuse their parents' aid, even if they want to, especially if the latter can help. At the same time, youth consumption remains independent: a young man or woman almost always have 'their own money'. It is not included into everyday expenses of the family and is spent on household needs only in case of a dire emergency. Depending on the field of employment, young people in this group have different spending strategies with different directions. Private sector employees spend money to demonstrate their freedom of choice - it is important for them to buy quality goods at reasonable prices. Public sector employees use spending to maintain their style and spend time with their friends. Self-employed youth see spending as an investment, emphasising its usefulness.

\section{Conclusion: has the crisis taken its toll?}

The analysis of consumer strategies of Russian urban youth with different work experience was conducted during the beginning of a financial crisis aggravated by European and North American sanctions against Russia. The article reflects the very first reactions of urban youth to the deterioration of the overall negative socioeconomic environment in the country. Let us summarise how Russian youth with different work experience manage their time and money today and see if the ongoing crisis establishes new consumer behaviour patterns among urban youth in modern Russia.

We can state that the consumption of urban youth with different work experience is developing in a rather passive way and that, in general, it follows a familiar pattern. It is hardly possible to call it entirely informed. Young people struggle with accepting the circumstances of the crisis; it is difficult for them to break the habit of the established behavioural patterns in consumption (propaganda in the context of absolute loyalty to the authorities is doing a good job). In general, we can say that young people, regardless of their age and field of employment, are still quite slow in accepting the new socioeconomic conditions they find themselves in today. 
We do not yet observe a total shift to abandonment of the usual goods and services. Contrary to researchers' forecasts (Radayev, 2005), fewer consumption opportunities, which is an inevitable result of the redistribution of work and leisure time (in favour of work), have only partially led to the forced abandonment of consumer claims. They mostly contribute to a gradual transformation and a gradual formation of other (new) consumer strategies among young people. For example, youth's consumer ambitions still revolve around well-known brands. However, the example of young people with a longer job tenure (about ten years) is already indicating changes in the meanings that are now beginning to dominate in purchasing practices. The focus is gradually shifting from status to quality, which, in the conditions of the (expected) import deficit, becomes an important characteristic that determines the value of goods and justifies consumer choices.

As for informed consumption, it is just beginning to take shape and gain value among Russian youth, but not in the 'political dimension', identified by some researchers as its precondition (Ward Claes de Vreese, 2011). Even despite the fact that, in an attempt to find a rational explanation for what political nuances explain their deteriorating situation today, young Russians are perhaps the most progressive and responsive part of Russian society; the awareness of Russian youth today is being formed in the context of everyday behaviour. Their informed consumption is not political, but domestic and can be viewed as a forced private reaction to the current economic situation. As a result, a feature of young people's coping with the crisis at its present stage is the strengthening of individualistic trends in their consumer choices and strategies.

Consumer transformations manifest themselves in the gradual downward trend in the volume of consumed goods and services. They are especially evident in the low-income group of public sector employees; both those with about ten years of work experience and those new to the labour market. In this respect, young people with different work experience turned out to be in the same boat: in the distribution of their expenses, they invariably place food in the first place, whereas at times there is simply not enough money to spend on other things.

Another indicator of the reduction in youth consumption is the shift away from public forms of leisure to home (private) space. Private consumption takes various forms of home pastime. Which, on the one hand, once again, points to individualistic consumption trends that are gaining momentum today. Additionally, on the other hand, it suggests the growing role of domestic practices and friendship networks in saving the important function of leisure consumption. In these circumstances, time spent on friends can be equivalent to (financial) investments.

We agree with Tsai C.I. and Zhao M. (Tsai \& Zhao, 2011) that during a crisis young people begin to intentionally manage their time, projecting their expenses on goods and services. In our case, young people employ a rational approach to how much time they can spend on leisure, on friends and on work. However, we should note that they do not literally control their time. Young people desperately try to control it, but the difficult situation in the labour market makes it hard to achieve this goal. Our data show that, incredible as it may seem, self-employed youth is one of the most vulnerable groups in this respect, even though they seem to be free to manage their time as they see fit. However, it has turned out that the need to constantly look for earning opportunities in a crisis environment required freelancers to make larger resource investments, with their prospects remaining uncertain. At the same time, young public and private sector employees' schedules have proved to be more or less stable. However, it does not mean that public sector employees or young entrepreneurs feel more confident in managing their time. For all the three groups, the idea of control takes shape in the principle of time monetisation. This pursuit erases the boundaries between 'work' and 'not work'. Today we can assert that free time has almost no value for young people, regardless of their work experience. In addition, the status of employment changes its 
meaning (especially among young private sector employees and, to some extent, those in the public sector). In some cases, work becomes not so much a means to earn one's living as an activity.that can, for example, result in blurred boundaries between what is defined as 'work' and what is considered a 'hobby'. All these transformations can also be viewed as forms of Russian urban youth's response to the crisis.

The current economic crisis aggravated by sanctions, puts young people with different work experience in unequal risk situations, which is neutralised by different strategic resources. Some are forced to normalise the situation with the help of their planning competencies, some resort to saving practices in a crisis, some continue to rely on parental support, some choose to rely on friendship networks, etc. In general, we can say that, in the current crisis, young people are the most vulnerable population group, especially those who have only recently entered the labour market. Uneven and spontaneous financial behaviour and the lack of long-term plans, which is characteristic of this age group, even if there is a certain degree of awareness, put them in forced consumption situations, thereby increasing social inequality.

\section{References}

Abraham, I. (2013), Pentevangelical Youth Subcultures: Between Resistance and Compromise, Youth Studies Australia, Vol. 32, No. 3, pp. 3-12.

Beck, U. (2009), World at Risk, Cambridge: Polity Press.

Bennett, A. (2011), The post-subcultural turn: Some reflections ten years on, Journal of Youth Studies, Vol. 14, No. 5, pp. 493-506.

Benson, A. L. I. (2000), I Shop, therefore I am: Compulsive Buying and the Search for Self, Northvale, NJ: Jason Aronson.

Brown, A. and Spencer, D. A (2014), Understanding the Global Financial Crisis: Sociology, Political Economy and Heterodox Economics, Sociology, Vol. 48, No. 5, pp. 938-953.

Chatzitheochari, S. and Arber, S. (2012), Class, gender and time poverty: a time-use analysis of British workers' free time resources, The British Journal of Sociology, Vol. 63, No. 3, pp. 451-471.

Consumer Behaviour of Russians during the Crisis, http://fom.ru/Ekonomika/12100 (retrieved: 16.04.2015).

Croghan, R., Griffin, C., Hunter, J. and Phoenix A. (2006), Style Failure: Consumption, Identity and Social Exclusion, Journal of Youth Studies, Vol. 9, No. 4, pp. 463-478.

Epstein, C. F, and Kalleberg, A. L. (2004), Time and Work: Changes and Challenges, Fighting for Time: Shifting Boundaries of Work and Social Life, eds. C. F. Epstein and A. L. Kalleberg, New York: Russell Sage Foundation, pp. 1-24.

Gurova, O. (2009), Fashion and Visualization of Social Change in the Modern Russian City, In: Visual Anthropology: urban memory card (Eds.), P. Romanov, P. and E. YarskayaSmirnova, Moscow: Variant CSPGS, pp. 275-293.

Hodkinson P. (2012), Beyond spectacular specifics in the study of youth (sub)cultures, Journal of Youth Studies, Vol. 15, No. 5, pp. 57-572.

Hodkinson, P. and Deicke, W. (2007), Youth cultures: scenes, subcultures and tribes, New York, London: Routledge.

How the Crisis Affects Russians, http://fom.ru/Ekonomika/12075 (retrieved: 16.04.2015).

Ilyin, V. (2005), Consumer Society: Theoretical Model and Russian Reality, World of Russia, Vol. 14, No. 2. pp. 3-40.

Klepach, A. (2015), Lessons from Modern Crisis for Economic Development in Russia, Journal of the New Economic Association, Vol. 26, No. 2, pp. 210-218. 
Koftunkin, D. (2011), The Development of Consumer Society in Russia: Consumer Lending, Journal of Sociology and Social Anthropology, Vol. 58, No. 5, pp. 99-107.

Lintsova, N. (2014), Models and Styles of Consumption in Transformed Societies, Sociological Almanac, No. 5, pp. 197-205.

Lukianova, E. and Sabirova, G. (2012), At Any Given Time, There Is a Crisis Somewhere: Characteristics of Young People Under the Conditions of the Economic Slump, Socis, No. 5, pp. 79-88.

Miles, S. (2000), Youth lifestyles in a changing world, Buckingham: Open University Press.

Omelchenko, E. L. and Pilkington, H. (2013), Regrounding Youth Cultural Theory (in PostSocialist Youth Cultural Practice), Sociology Compass, Vol. 7, No. 3, pp. 208-224.

Omelchenko, E. L. and Sabirova, G. (2015), Youth cultures in contemporary Russia: memory, politics, solidarities, Eastern European Youth Cultures in a Global Context, Palgrave Macmillan, pp. 253-270.

Pilkington, H. (2006), 'The More They Talk about it, the More You Feel like Doing it': Reflections on the Discursive Production of Generational Experiences, Anthropological Forum, No. 5. pp. 379-407.

Russian Federal State Statistics Service (2015), Preliminary Assessment of the Dynamics of GDP in the Second Quarter of 2015, http://www.gks.ru/bgd/free/B04_03/IssWWW.exe/Stg/d06/vvp10.htm (Retrieved: 15.05.2015).

Salzman, M. (2000), Rise of the prosumer, Marketing, Vol. 54, No. 6, pp. 141-153.

Scammell, M. (2000), The internet and civic engagement: the age of the citizen-consumer, Political Communication, Vol. 17, No. 4, pp. 351-55.

Shildrick, T. A. and MacDonald, R. (2006), In defence of subculture: young people, leisure and social divisions, Journal of Youth Studies, Vol. 9, No. 2, pp. 125-140.

The Dynamics of the Crisis Mood of Young People, http://bd.fom.ru/report/map/kr09mol (retrieved: 15.04.2015).

Strauss, A. and Corbin, J. (1998), Basics of qualitative research: Techniques and procedures for developing grounded theory, Sage Publications, Inc.

Synovate Comcon: Consumer Behaviour and Economic Attitude of Russians in the Beginning of 2015, http://gtmarket.ru/blog/comcon/2015/01/28/7072 (retrieved: 16.04.2015).

Tsai, C. I. and Zhao, M. (2011), Predicting Consumption Time: The Role of Event Valence and Unpacking, Journal of Consumer Research, Vol. 38, No. 3, pp. 459-73.

Ward Claes de Vreese, J. (2011), Political consumerism, young citizens and the Internet Media, Culture Society, Vol. 33, No. 3, pp. 399-413.

Weinzierl, R. and Muggleton D. (2003), The post-subcultures reader, London: Bloomsbury Academic.

Youth's Reserved Attitude towards the West, http://www.levada.ru/16-04-2015/molodezh-kzapadu-otnositsya-sderzhanno (retrieved: 15.05.2015). 